\title{
Resistivity and induced polarization applied to "Buraco do Inferno" Cave, São Desidério, State of Bahia, Brazil
}

Rodoilton Stevanato, LPGA-UFPR, Francisco José Fonseca Ferreira, LPGA-UFPR; Rafael Espindola Canata, LPGA-UFPR; Dyeison Cesar Mlenek, ITTI-UFPR; Anival Antonio Leite, ITTI-UFPR; Durval Nascimento Neto, ITTI-UFPR.

Copyright 2019, SBGf - Sociedade Brasileira de Geofísica

This paper was prepared for presentation during the $16^{\text {th }}$ International Congress of the Brazilian Geophysical Society held in Rio de Janeiro, Brazil, 19-22 August 2019.

Contents of this paper were reviewed by the Technical Committee of the $16^{\text {th }}$ International Congress of the Brazilian Geophysical Society and do not necessarily represent any position of the SBGf, its officers or members. Electronic reproduction or storage of any part of this paper for commercial purposes without the written consent of the Brazilian Geophysical Society is prohibited.

\begin{abstract}
Induced polarization (IP) and resistivity (Res) methods were used at "Buraco do Inferno" cave, associated with João Rodrigues River Karst System, to detection subsurface dissolution zones in limestone rocks of the Bambuí Group in São Desidério region, State of Bahia. The IP delimited the coverage zone formed by sandstoneclay soils, while the resistivity determined conductive zones within the limestone domain below the soil layer. In these conductive zones, the caves with resistivity less than 300 Ohm.m were interpreted, which concur with the saturated zone. Given the obtained results we verified that the resistivity obtained the optimum identification of the cavities and geoelectric discontinuities. The chargeability was complementary in the identification of the cover layer given by the membrane polarization formed by the clayey constituents.
\end{abstract}

\section{Introduction}

The study was developed through technical cooperation between the Laboratory for Research in Applied Geophysics and the Technological Institute of Transport and Infrastructure, both at the Federal University of Paraná. To meet the objectives of the agreement with the National Department of Infrastructure and Transport, the focus of this work is to present results regarding the acquisition, processing, and interpretation of induced polarization and resistivity data in the detection of cavities in the João Rodrigues River Karst System. This work is part of a set of research activities in karstic terrains along the BR-135 highway in the locality of Buraco do Inferno, municipality of São Desidério, State of Bahia, Northeast of Brazil (Fig. 1).

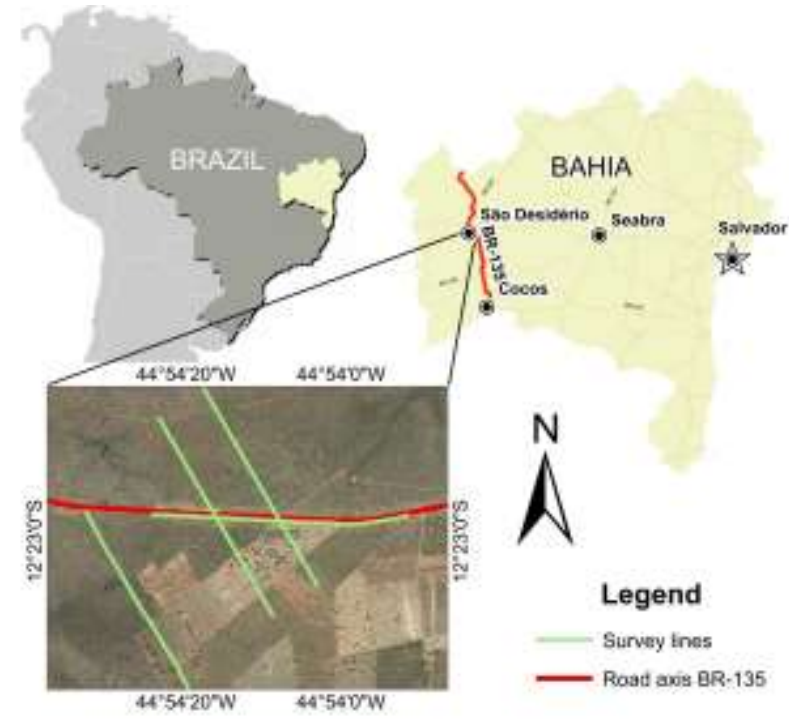

Figure 1 - Location map of the BR-135 Project - São Desidério - West State of Bahia - Brazil.

\section{Study area and geologic setting}

The work carried out in the study area involved the acquisition of four lines superimposed on the digital elevation model, as indicated in figure 2. Limestones of the São Desidério Formation form the geological context, Bambuí Group in intracratonic and offshore epicontinental basins of Neoproterozoic age positioned northwest of São Francisco Craton (Almeida 1977). Lithologically, there are predominantly pure and homogeneous gray-dark limestones with metamorphism in the green facies and deformed with fractured rupture (faults, fractures, and joints) and ductile with various forms of folds. The João Rodrigues River Karst System in which the "Buraco do Inferno" cave is controlled by a set of faults and fractures in the preferred direction NE-SW and NW-SE subordinates (Fig. 3). Superimposed on the limestones occurs a cover with unconsolidated sediments formed predominantly by sand and subordinate silt-clay of Tertiary and Quaternary age. 
Resistivity and induced polarization applied to "Buraco do Inferno" Cave.

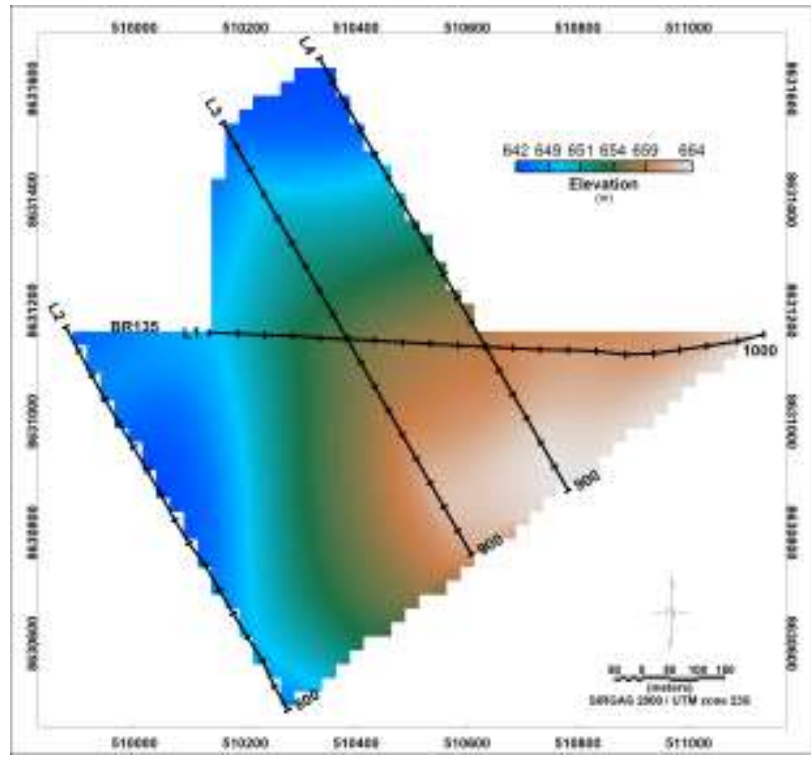

Figure 2 - Location map of geophysical lines with Digital Elevation Model.

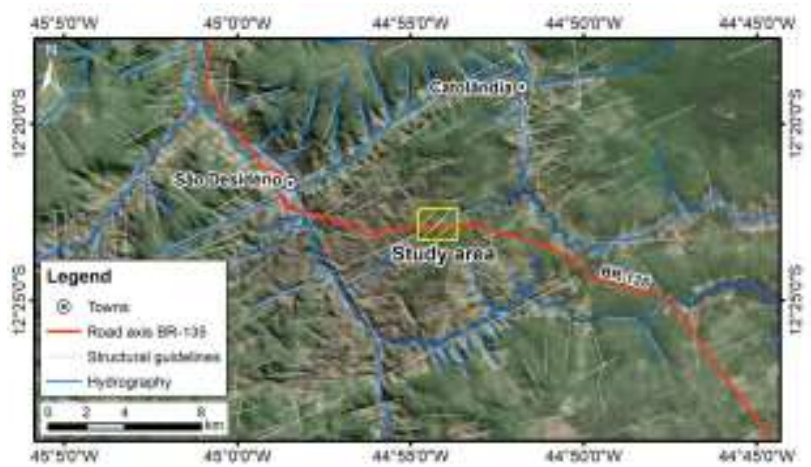

Figure 3 - The main structural lineaments in the study area.

\section{Methodology}

Before the geoelectric survey, the positioning of the measurement stations in the field was necessary (Figure 4). For the location, the real-time geodetic positioning (RTK) method was used. The ellipsoidal altitudes obtained by the geodetic positioning were reduced to the geoid employing MAPGEO2015 geoidal wave interpolation system (Mlenek et al., 2017).

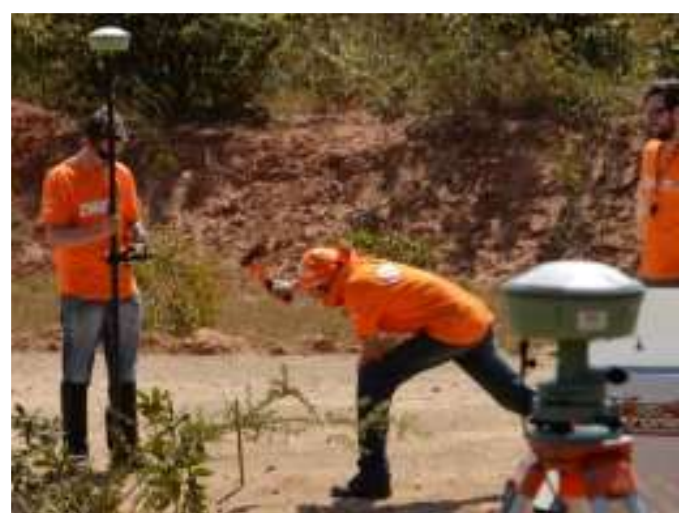

Figure 4-Positioning of the measurement stations.
The geoelectrical acquisition system consists of one current transmitter VIP3000W and one potential receiver ElrecPro with 10 channels from the branch Iris Instruments, besides electrodes and cables. To inject current in the ground, two common steel electrode was needed while to measure the potential field we employ a set of permeable and non-polarizable electrodes (Fig. 5). All devices were connected with conductive cables. The configuration chosen was the dipole-dipole array with an electrode spacing of $50 \mathrm{~m}$ and 6 levels of investigation. The dataset comprises 4 lines of $1 \mathrm{~km}$ length (L1), 0,8 km (L2) and $0,9 \mathrm{~km}$ (L3 and L4), resulting in a total of $3,6 \mathrm{~km}$ of the geophysical profiles.

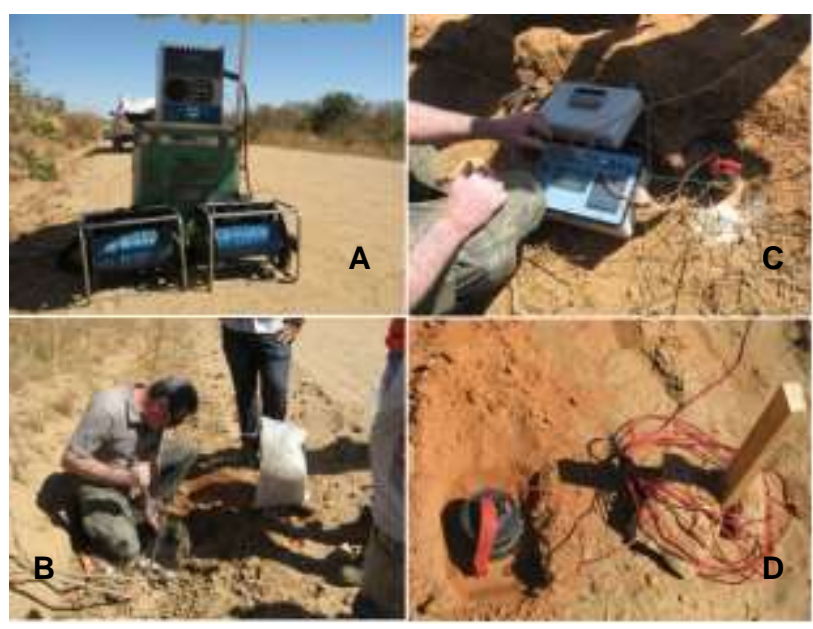

Figure 5 - IP and Res data acquisition. A) VIP transmitter; B) steel electrode; C) ElrecPro receiver; $D$ ) non-polarizable electrodes.

For the IP and Res inversion, we used the software Geosoft 8.5 with the Zonge extension. The 2D plot sections were possible through the IP module of the same software. Pseudo-sections using the Hallof (1957) projection were inverted with 9 iterations based on Edwards (1977). Thus, we generate IP and Res depth models (Fig. 6) that represent the "real" geoelectric behavior of chargeability and resistivity of the subsurface, respectively, with a depth of investigation of $86 \mathrm{~m}$, multiplied by two during the inversion. Figure 6 constitutes the database to generate 2D maps and 3D blocks.

\section{Results}

Figure 6 present the depth models of chargeability and resistivity of the lines L1, L2, L3 and L4 (Stevanato et al., 2018). The top panel of $L 1$ shows a polarized cover zone given by the clayey-sandy soil in contrast to the lower feature of the unpolarized Bambuí Group limestones, given by the $7 \mathrm{mV} / \mathrm{V}$ isocurve over almost the entire length of the section. In the lower panel of the figure, a subhorizontal geoelectric pattern is a reflection of a resistive cover composed of sandy soil with a clayey contribution, superimposed on a conductive tract of the Bambuí Group limestones. In the station $600 \mathrm{~m}$ is indicated a conductive geoelectrical discontinuity, suggesting the presence of saturated cavities and possibly connected by horizontal conduits. The direction of Line L1 makes a 45 degrees angle with the structure of the João Rodrigues River Karst System that houses the 
Cave of the "Buraco do Inferno", so the thicknesses of the possible cavities shown in the section are apparent.

Line L2 shows in the top panel a cover with low polarization indices given by the same type of sandy and clayey soil of small thickness and not very expressive and, for this reason, is not marked according to the scale of the model. In the deeper tracts a zone with higher polarization occurs that correlates to the massive limestones. In the lower panel, the resistivity also shows a subhorizontal pattern, whose contact between the saturated zone and the lower massive limestones is delineated by the $2000 \mathrm{Ohm}$.m. Within the saturated zone were marked five places where dissolutions should occur, being the most expressive located in stations 300 and $400 \mathrm{~m}$.

The top panel of Line L3 revealed a chargeability pattern marked by the sub-horizontal contrast of polarized tracings in the surface layers resulting from sandy-loamy soils whose contact with the lower low-load tracts of the Bambuí Group limestone occurs around $50 \mathrm{~m}$ depth. In the lower panel, a resistive cover is correlate with the clayey-sandy soils in contrast to the lower conductive layers that probably reflect saturated Bambuí Group limestones. Some nuclei are suggestive of small dissolutions in the lithological domain mentioned, that present, in this place, more resistive behaviors in the inferior tracts of the massive limestones.

The top panel of Line $L 4$ revealed a chargeability pattern similar to that of Line L3, marked by the sub-horizontal contrast of polarized levels on the surface layers of clayey-sandy soils, whose contact with the low chargeability lower traces reflects the limestones around $50 \mathrm{~m}$ deep. In the lower panel, a resistive cover reflects the clayey-sandy soils in contrast to the lower conductive layers that correlate with the probably saturated Bambuí Group limestones. A small nucleus suggestive of dissolution within the aforementioned lithological domain, show less resistive behavior in relation to the deeper ones.

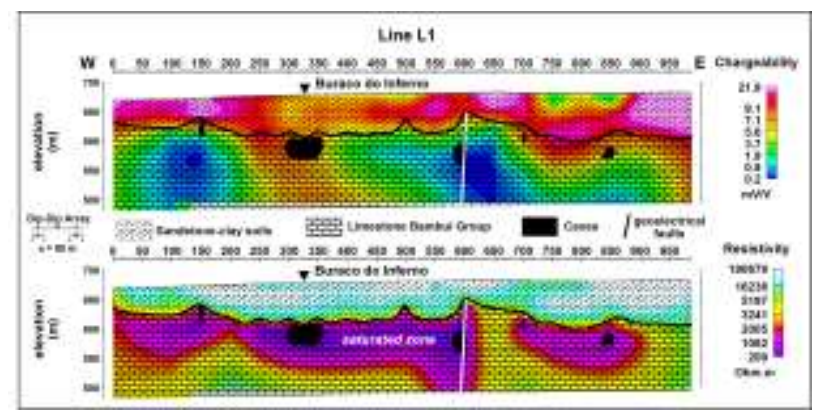

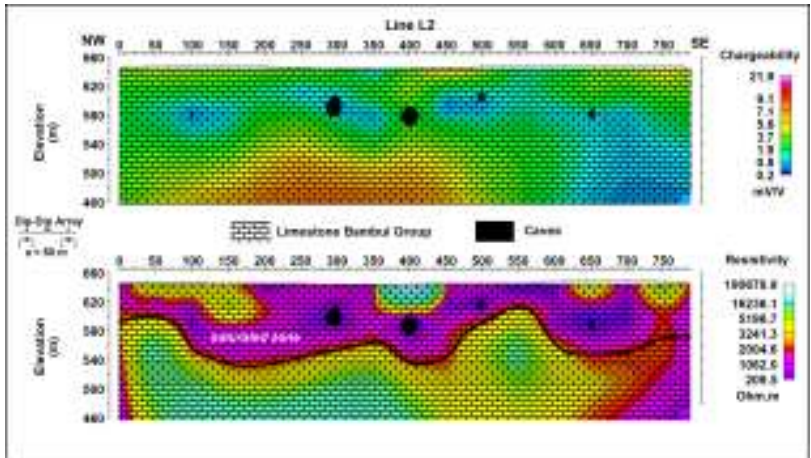

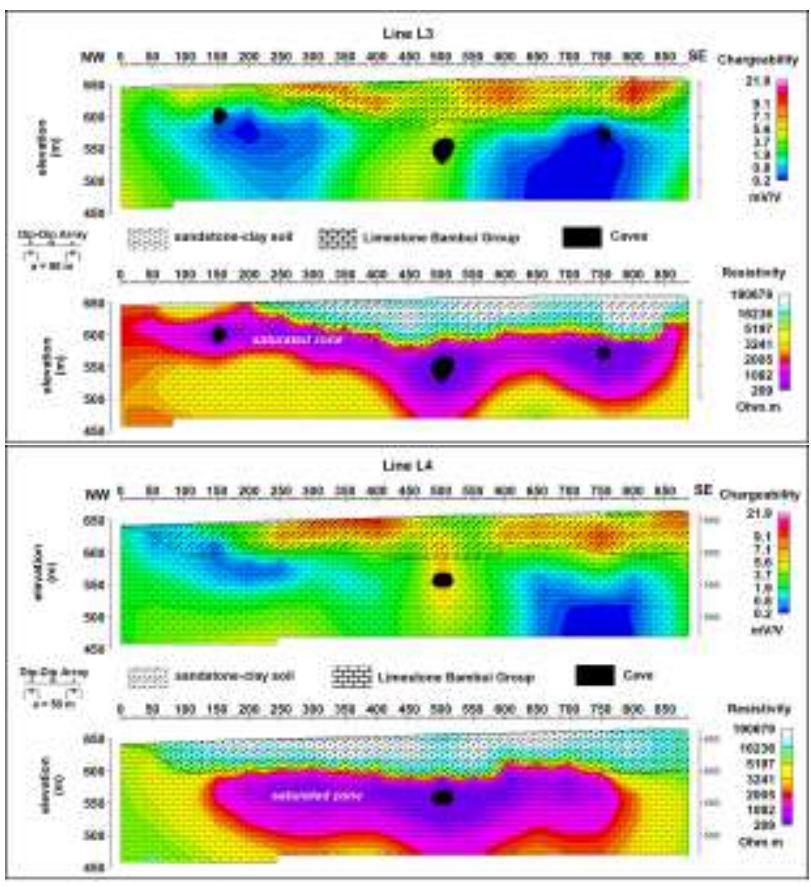

Figure 6 - Chargeability (top panel) and resistivity (bottom panel) depth models of the lines L1 to L4 (see location - Fig.2).

The maps of figure 7 represent two depth levels, one at $64 \mathrm{~m}$ (top panel) and the other at $96 \mathrm{~m}$ (bottom panel), which were interpreted, respectively, as the ceiling and base of the "Buraco do Inferno" cave. Note that resistivity values decline abruptly in contrast to adjacent treatments. At a depth of 96 meters, interpreted as the base of the cave, the less resistive environment is more pronounced than in the vicinity of the ceiling, forming a more saturated zone. At a depth of $64 \mathrm{~m}$ the geoelectric discontinuity is well marked by low resistivity and at a depth of $96 \mathrm{~m}$ the continuity of the structure that houses the "Buraco do Inferno" cave is suggested. 
Resistivity and induced polarization applied to "Buraco do Inferno" Cave.

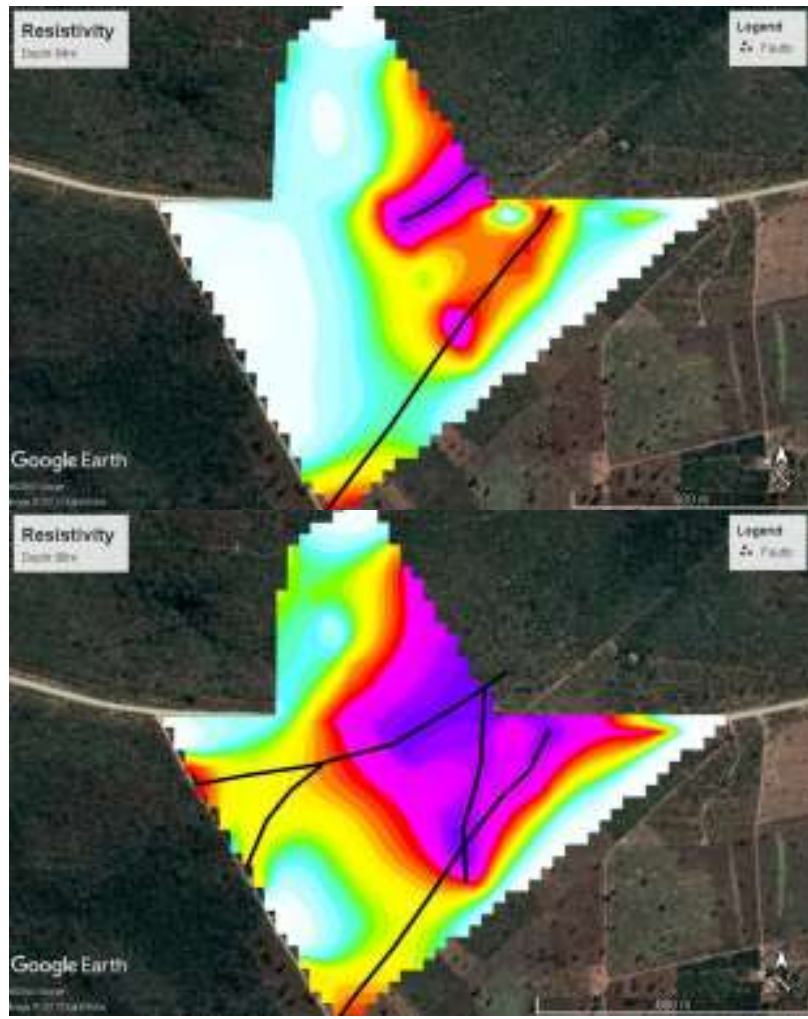

Figure 7 - Slice maps at depths of $64 \mathrm{~m}$ (top panel) and $96 \mathrm{~m}$ (bottom panel)

The three-dimensional model illustrated in figure 8 shows the cave within the limestone domain of the Bambui Group. The block diagram (Fig. 8) was constructed from the integration of lines L1, L3 and L4. The low resistivity (hot colors), is interpreted as the geophysical signature of the cave, which is indicated by 3D model (Fig. 9).

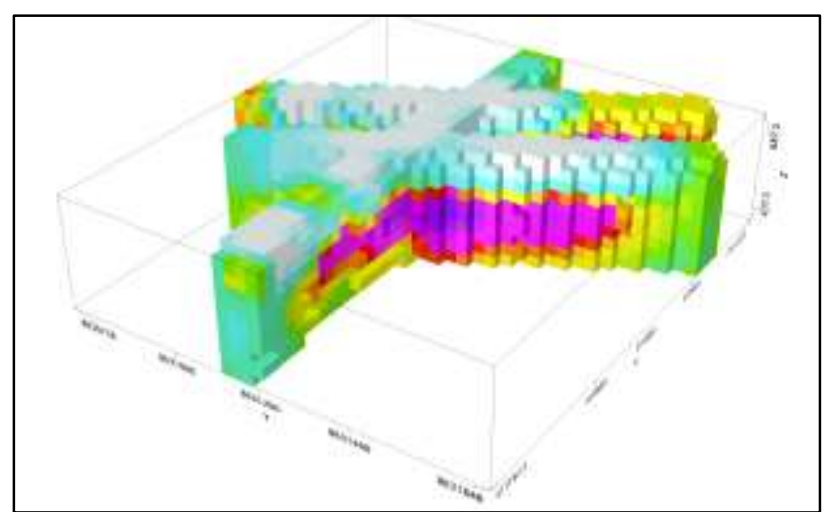

Figure 8 - Three-dimensional model indicating the geophysical signature of the "Buraco do Inferno" cave (low resisitivity, hot colors).

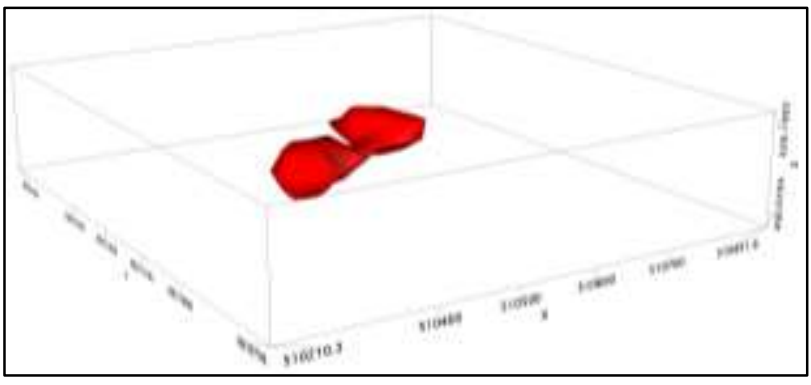

Figure 9 - Three-dimensional models of the "Buraco do Inferno" cave.

\section{Discussion}

In the map of geophysical interpretation of figure 9 is represented the projection of the "Buraco do Ïnferno" cave, with axis centered in the station $500 \mathrm{~m}$ (L3 and L4) and $325 \mathrm{~m}$ (L1). Another outstanding feature is a geoelectric discontinuity of low resistivity, which may be related to the dissolution structure subparallel to the main axis of the cave. Based on the geophysical results obtained along lines L1, L3 and L4, it was possible to establish the dimensions of the cave, according table 1, which were confirmed by the visual inspection shown in figure 11 .

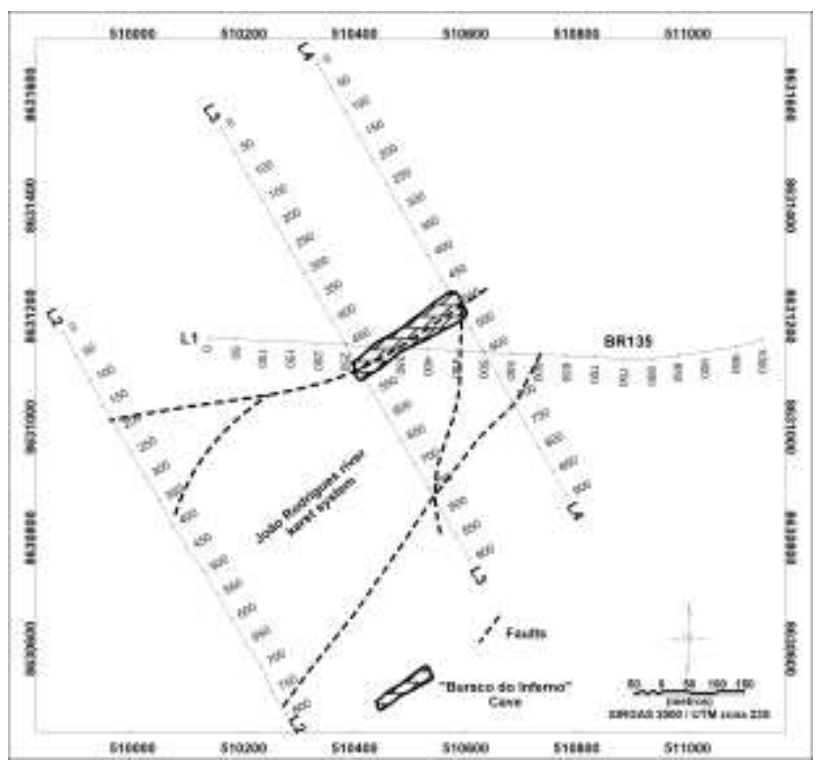

Figure 10 - Geophysical interpretation map indicating the position, projection and geoelectric discontinuities of the "Buraco do Inferno" cave.

Table 1 - Results of the location and dimensions of the "Buraco do Inferno" cave by geophysical studies.

\begin{tabular}{|c|c|}
\hline \multicolumn{2}{|c|}{ "Buraco do Inferno" Cave - BR135 } \\
coordinates 510462E x 8631144N (Sirgas 2000) \\
\hline ground altitude & $680 \mathrm{~m}$ \\
\hline top altitude & $610 \mathrm{~m}$ \\
\hline floor altitude & $570 \mathrm{~m}$ \\
\hline depth of the top & $70 \mathrm{~m}$ \\
\hline width & $50 \mathrm{~m}$ \\
\hline height & $40 \mathrm{~m}$ \\
\hline
\end{tabular}




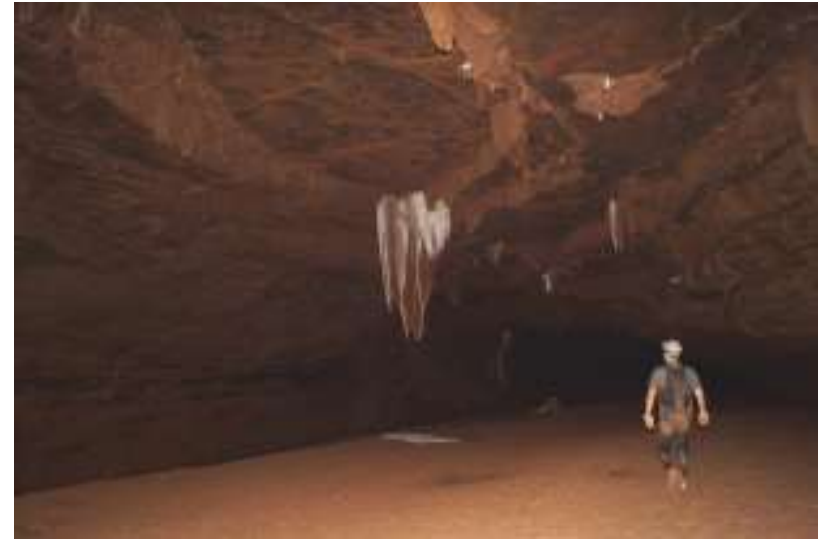

Figure 11 - Visual inspection of "Buraco do Inferno" cave.

\section{Conclusions}

The results of the resistivity method allowed discriminating conductive zones associated with possible cavities and saturated area of the Bambuí Group limestones. The sites with high resistivities are related to sandy-clayey cover or massive limestone.The "Buraco do Inferno" cave is located beneath the highway bed at a depth of 70 meters from the surface to its roof, whose cover is composed by a sandy-clayed resistive layer. Underlying this layer, saturated limestones of the Bambuí Group with dissolution features exhibit low resistivity. Areas of faults/fractures that caused the dissolution and formation of the main cave with 50 meters of thickness and 40 meters of height from the roof to the floor, according to the geophysical data, which were confirmed later by direct works, form the João Rodrigues River Karst System.

\section{Acknowledgments}

The authors are grateful to the 2014-2016 management board of the National Department of Infrastructure and Transport (DNIT) for funding the research through the DNIT/ITTI/UFPR agreement. We also thank the students of the geology course of the Federal University of the West of Bahia (UFOB) and Professor Leandro Moutinho. The National Council for Scientific and Technological Development (CNPq, Brazil) supported F.J.F. Ferreira in this research (contract 303826/2018-5).

\section{References}

Almeida, F.F.M. 1977. O Cráton do São Francisco. Revista Brasileira de Geociências, vol.7, 349-364p.

Edwards L.S. 1977. A modify pseudo-section for resistivity and IP. Geophysics, 42(5): 1020-1036.

Hallof P.G. 1957. On the Interpretation of Resistivity and Induced Polarization Results. Thesis (Ph. D.) Massachusetts Institute of Technology. Dept. of Geology and Geophysics.
Mlenek, D.C.; Arenas, F.C.; Ferreira, F.J.F.; Canata, R.E.; Moro, R.C. e Stevanato, R. 2017. Modelagem Tridimensional da Caverna Buraco do Inferno na Rodovia BR-135 no Município de São Desidério - BA. Anais do XXVII Congresso Brasileiro de Cartografia, SBC, Rio de Janeiro, RJ, p.193-197.

Stevanato, R.; Canata, R.E.; Ferreira, F.J.F. 2018. Projeto BR135 - Buraco do Inferno, São Desidério - BA (Polarização Induzida e Resistividade na detecção de cavidades). LPGA\&ITTI, Curitiba, Brasil, Relatório inédito, $34 p$. 